\title{
Survey and Field Measurement on Residential Lifestyle and Energy Use in Rural China
}

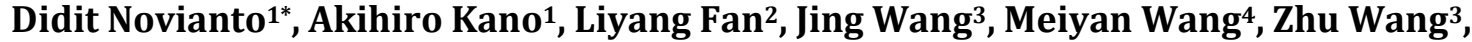 \\ Jian $\mathrm{Ge}^{3}$, Yong $\mathrm{He}^{3}$, Weijun $\mathrm{Gao}^{1}$ \\ ${ }^{1}$ Environmental Engineering, The University of Kitakyushu, Kitakyushu, Japan \\ ${ }^{2}$ Kobe Institute of Computing, Kobe, Japan \\ ${ }^{3}$ Architectural Department, Zhejiang University, Hangzhou, China \\ ${ }^{4}$ School of Landscape and Architecture, Zhejiang A\&F University, Hangzhou, China \\ Email: ${ }^{*}$ u3dbb002@eng.kitakyu-u.ac.jp
}

Received 5 August 2015; accepted 23 October 2015; published 26 October 2015

Copyright (C) 2015 by authors and Scientific Research Publishing Inc.

This work is licensed under the Creative Commons Attribution International License (CC BY). http://creativecommons.org/licenses/by/4.0/

c) (i) Open Access

\section{Abstract}

In the middle of May to September 2014, the research team conducted survey and field measurement on rural residential energy consumption and environment condition in China's local city in order to grasp the lifestyle pattern and its correlation on energy use in the demand side. In this paper, the analyses of people lifestyle and summer energy consumption will be presented through statistical analyses based on data which collected from questionnaire survey. The results of questionnaire were presented and discussed. Based on the questionnaire results, we classified the housing types into several groups then compared the energy use of each type. The major influential factors on housing energy consumption were analyzed and the results were discussed. The results of field measurement during summer which conducted to several types of houses were also discussed. Finally, the results will propose some strategies on lowering housing energy use in the village. Further, the results will give conceptual layout to find the correlation between environmental quality, thermal condition, and energy consumption.

\section{Keywords}

Village Housing, Lifestyle, Energy Use, China

\footnotetext{
${ }^{*}$ Corresponding author.
} 


\section{Introduction}

Due to the high economic growth of China, the urban areas and even in rural areas development became difficult to control. In addition, the people's lives standards also improved and hard to grasp. On the other hand, more and more households with higher incomes are becoming interested in using quality energy sources and the energy consumption in housing sector has increased with the improvement of living standards [1].

To meet the great demand of rural residential energy consumption, about 300 million tons of standard coals per year (quarter of total energy consumption of the whole country) are utilized [2]. Gu et al. [3], conclude that the great differences of natural resources, economic levels, and local government policies between one to another lead to the rural energy consumptions of different provinces having their own characteristics, which became problems on the expansion of commercial energy use in recent years. The condition of actual rural residential energy utilization and alteration to the energy structure that occurred in some countries in the last decade are analyzed by Feng et al. [4], Wang et al. [5], based on investigations by the agricultural ministry. Zhang et al. [6], investigated how rural residential commercial energy consumption evolves in China by applied the decoupling index combined with LDMI method has identified the contributing role of different factors affecting the change of rural residential energy consumption between 1991-2010. He et al. [7], concludes the rural building energy efficiency not only relates to strategic issues of China's energy security, national economy and people's livelihood, but also influences the global energy consumption and carbon emissions. Nagasaki et al. [8], did the questionnaire and analyzed the lifestyle of the occupants in the multiple housing in urban area of China. Many more researches of China's energy problem, but have not been revealed about the housing energy consumption in rural areas.

This study were conducted the questionnaire survey on housing characteristic and people lifestyle in order to understand the correlation between lifestyle and energy consumption. Also, the study would grasp the correlation between housing characteristics and thermal environment by field measurement. The study flow is shown in Figure 1.

In China, administratively, the cities and counties are under the province, and under the cities or counties there are regency and under the regency there are villages. Villages itself divided into main villages and sub villages. And a Wuwen village is belonging to the sub village of Jing Wu Village. The area was stand between the hills and follows the river side, shown in Figure 2. Mostly the people of Wuwen Village are working related with bamboo industry. Some are bamboo farmers, some have bamboo factory, and others are bamboo sellers, or working in outside the village. The village situation and daily activities were shown in Figure 3.

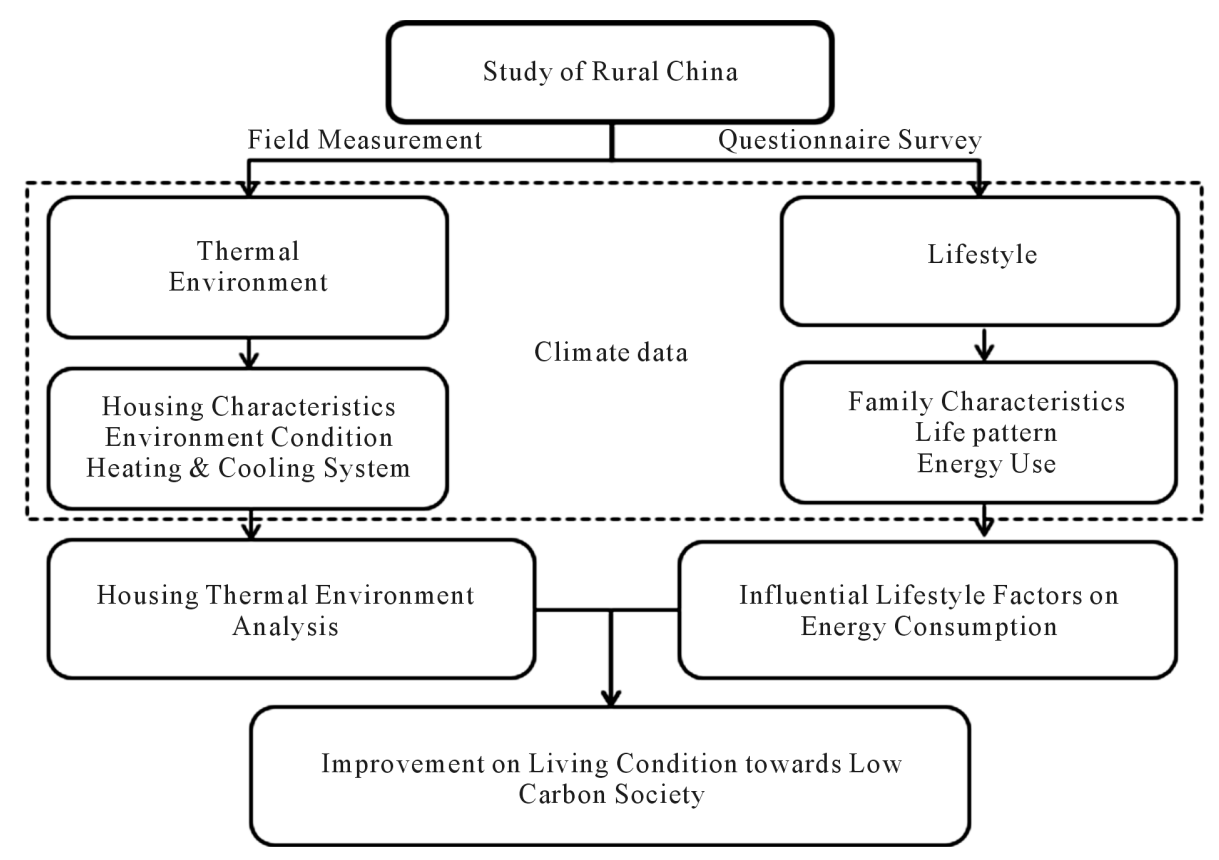

Figure 1. Research framework. 


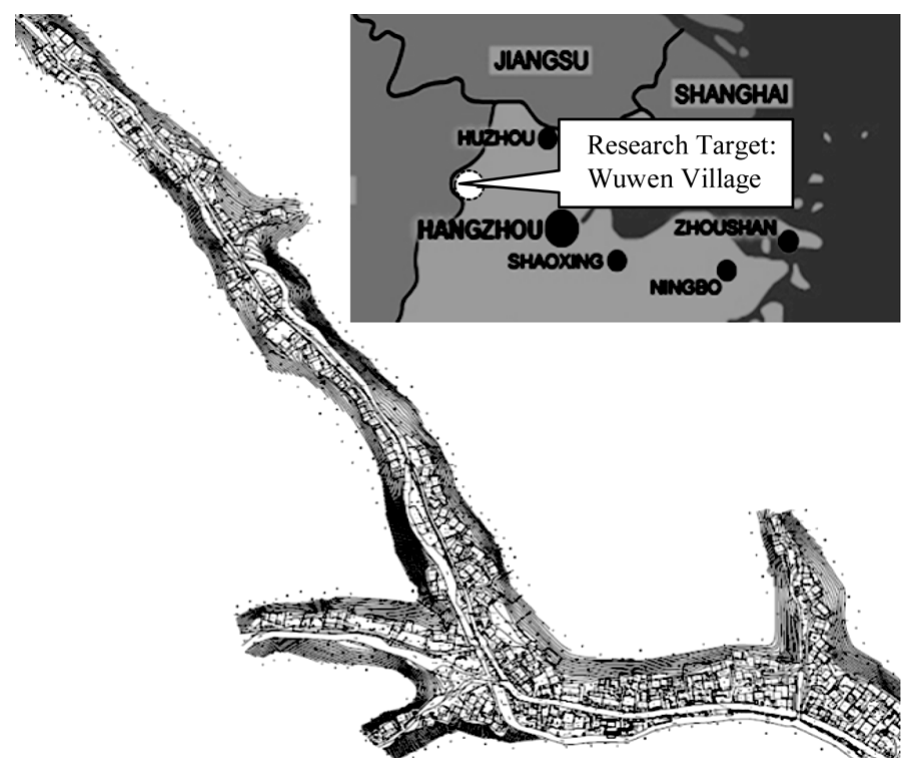

Figure 2. Study location, Wuwen Village, Anji, China.

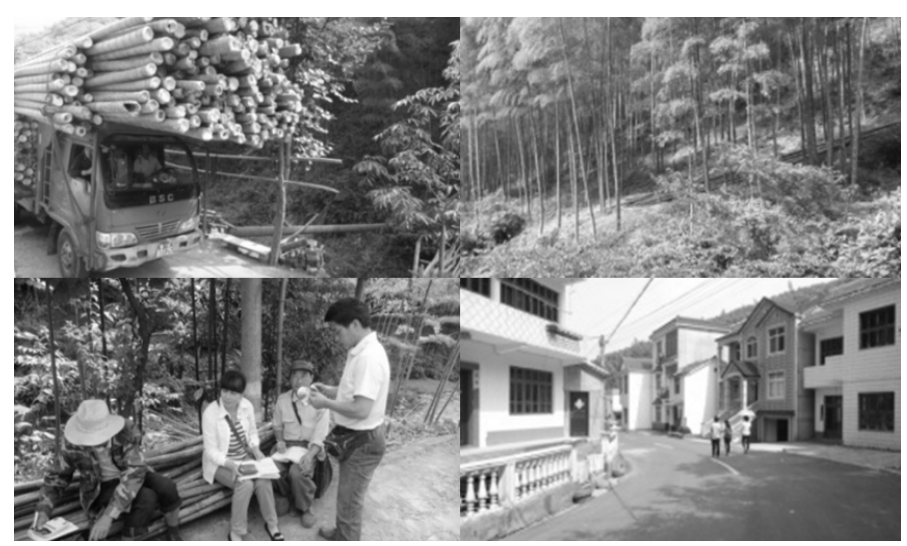

Figure 3. Villagers activities.

\section{Questionnaire Outline}

Table 1 show the basic information of the Wuwen village and questionnaire feedback number. From total 50 families (about 200 people) the team collected $86.1 \%$ feedback by hearing method. The questionnaire was conducted in the end of the summer season, between 20-21 September 2014. In another hand, the measurements which start from middle of May were also continued until in the end of September 2014. The questionnaire contents were shown in Table 2, divided into six categories includes of family characteristics, house characteristics, equipment, lifestyle pattern, energy consumption and also the opinion about their living environment condition.

\section{Questionnaire Results}

The results discussed in this paper are only the questionnaire results related with the occupant lifestyle and housing energy consumption.

\subsection{Family Characteristics}

Family member means the total person number included in each family. Even the person are not living in the village it is still being counted. The total numbers of family member who are staying or living in the village are called as occupant number in this research. Table 3 shows the summary of questionnaire results. Mostly in one 
Table 1. Basic information of survey.

\begin{tabular}{cccc}
\hline Population & Valid feedback & Questionnaire survey period & Measurement period \\
\hline 50 households & 31 households & $20-21$ Sept. 2014 & May-Sept. 2014 \\
$(<200$ people $)$ & $86.1 \%$ & & \\
\hline
\end{tabular}

Table 2. Questionnaire contents.

\begin{tabular}{cc}
\hline Category & Contents \\
\hline Family & Family member, family structure, annual income \\
House characteristics & Land size, floor size, construction year, house structure, envelope materials \\
House equipment & Heating-cooling system, appliances ownership, hot water supply \\
Lifestyle & Work hours, sleep hours, cooking hours, bathing hours, daily activity \\
Energy consumption & Electricity, gas, and water consumption \\
Living environment & Amenity, safety, health, convenience
\end{tabular}

Table 3. Questionnaire results.

\begin{tabular}{|c|c|c|c|c|c|}
\hline Item & Category & Percentage (\%) & Item & Category & Percentage (\%) \\
\hline \multirow{3}{*}{$\begin{array}{c}\text { Family member } \\
\text { (person) }\end{array}$} & $<2$ & 12.9 & \multirow{4}{*}{$\begin{array}{l}\text { Occupants number } \\
\text { (person) }\end{array}$} & 1 & 19.4 \\
\hline & $3-5$ & 64.5 & & 2 & 45.2 \\
\hline & $6>$ & 22.6 & & $3-4$ & 19.4 \\
\hline \multirow{3}{*}{ Floor number } & 1 & 12.9 & & $5>$ & 16.1 \\
\hline & 2 & 77.4 & \multirow{7}{*}{ Floor size $\left(\mathrm{m}^{2}\right)$} & $<50$ & 3.2 \\
\hline & 3 & 9.7 & & $51-100$ & 9.7 \\
\hline \multirow{5}{*}{ Main structure } & Brick \& concrete & 80.6 & & $101-150$ & 16.1 \\
\hline & Reinforce concrete & 6.5 & & $151-200$ & 6.5 \\
\hline & Wood & 3.2 & & $201-250$ & 32.3 \\
\hline & Brick & 3.2 & & $251-300$ & 9.7 \\
\hline & Other & 6.5 & & $301>$ & 19.4 \\
\hline \multirow{6}{*}{ Annual income } & $<5000$ & 6.3 & \multirow{6}{*}{ Building age } & $0-5$ & 9.7 \\
\hline & $5000-10,000$ & 12.5 & & $6-10$ & 16.1 \\
\hline & $11,000-35,000$ & 12.5 & & $11-15$ & 19.4 \\
\hline & $36,000-55,000$ & 31.3 & & $16-20$ & 16.1 \\
\hline & $56,000-100,000$ & 25 & & $21-25$ & 19.4 \\
\hline & 100,000 & 12.5 & & $25>$ & 19.4 \\
\hline
\end{tabular}

household is consisted of three to five people (about $64.5 \%$ of the feedback). Although there are some numbers of more than six member families (about 22.6\%) and the highest number of family member was 10 people. More than half from the feedback, the family structure are dominated by three generation (parent-married couple-child). In terms of occupant's number, it is shows contrarily results, mostly were occupied by only two people, the percentage are $45.2 \%$. By average, the family size was 4.6 people per households and number of people living was 2.7 people per households. This is due to there are more family member who worked and 
lived outside of the village (near the urban areas).

\subsection{House Characteristics}

Refer to Table 3, about 9.7\% of building age is less than five years, it can be seen that the building age is widely distributed at more than twenty years old houses which is about $39.2 \%$ of total feedback. The oldest house was built in 46 years ago. The total floor area dominated by 200 to $250 \mathrm{~m}^{2}$, counted about $32.3 \%$ of total feedback. From the results, mainly the houses are two-story houses, which is $77.4 \%$ from total. Even so there is significant number of three-story house reached $9.7 \%$ from total respondents. In terms of building structure, mainly the building was built with concrete as the main structures and brick as the wall structures. The annual income of family are varying but dominated by families with annual income of 35,000 to 55,000 Yuan per year (1.00 Yuan $\approx 0.15$ USD).

\subsection{House Appliances}

The possession of household appliances is shown in Figure 4. The electric Air-conditioner (AC) ownership number shows the high percentage, which more than half of households are using electric AC but the most popular appliances were a washing machine, it is $77 \%$ of ownership. Commonly, the villagers who did not use washing machine are doing the laundry in the river side that flows through the village. In the other hand, households who do not own electric AC are using the electric fan for cooling and firewood or charcoal in the winter season. Based on these result, when the annual income increased, the increased of possession on space heatingcooling equipment was also increased significantly. Figure 5(b) shows the percentage of water heating equipment possession. About $40 \%$ of households are using traditional way to get the hot water by firewood. But in the other hand, the number of solar water heater also shows high percentages which about $24 \%$ of surveyed households are installing the solar water heater.

\subsection{Residential Energy Consumption}

All energy units from the survey of each household, including electricity and gas, were converted into calorific value (Joules) so the energy consumption per year in the demand side can be presented. The energy conversion values used are shown in Table 4.

As a result, the annual energy consumption of each house is shown in Figure 6. The total energy consumption by households shows very high amount, reached almost $12 \mathrm{GJ} /$ year. But in the other hand, the result shows very high differences between the highest and the lowest energy consumption, which is only less than $1 \mathrm{GJ} / \mathrm{year}$, there are nearly ten times difference, even in the same village area. However, in case of the energy consumption per capita, the difference shrinks to about six times smaller between the highest and the lowest energy consumption. Since some of the houses were only lived by small number of occupants, the energy used for bigger houses seem too high and wasted. In other hand, the consumption of water is very hard to grasp due to almost $100 \%$ of villagers are using the water from the river.

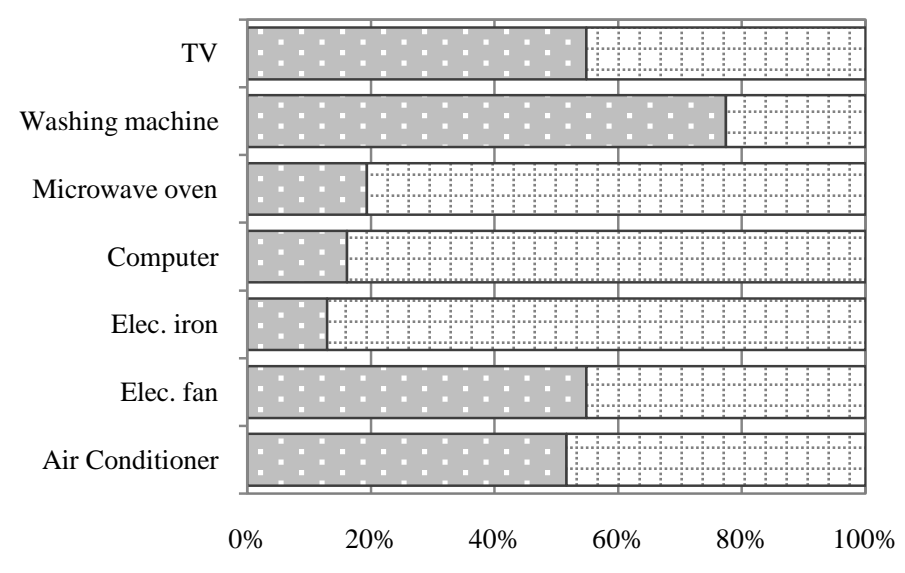

Figure 4. Appliances ownership. 
Table 4. Calorific value of energy consumption.

\begin{tabular}{cc}
\hline Categories & Value \\
\hline Electricity & $3.6[\mathrm{MJ} / \mathrm{kWh}]$ \\
Firewood & $28.9[\mathrm{MJ} / \mathrm{kg}]$ \\
Charcoal & $16.0[\mathrm{MJ} / \mathrm{kg}]$ \\
LPG & $42.3[\mathrm{MJ} / \mathrm{kg}]$ \\
\hline
\end{tabular}

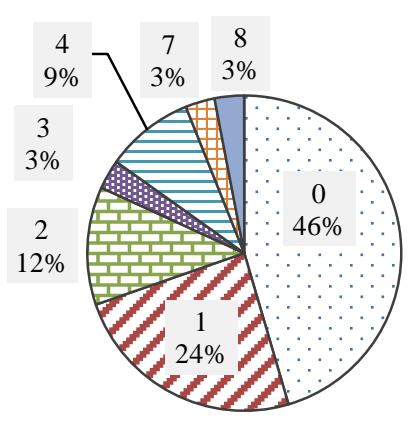

(a)

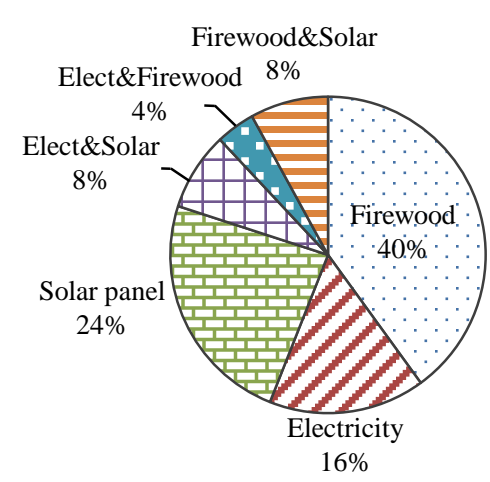

(b)

Figure 5. Cooling and hot water system. (a) AC ownership (unit); (b) water heating method.

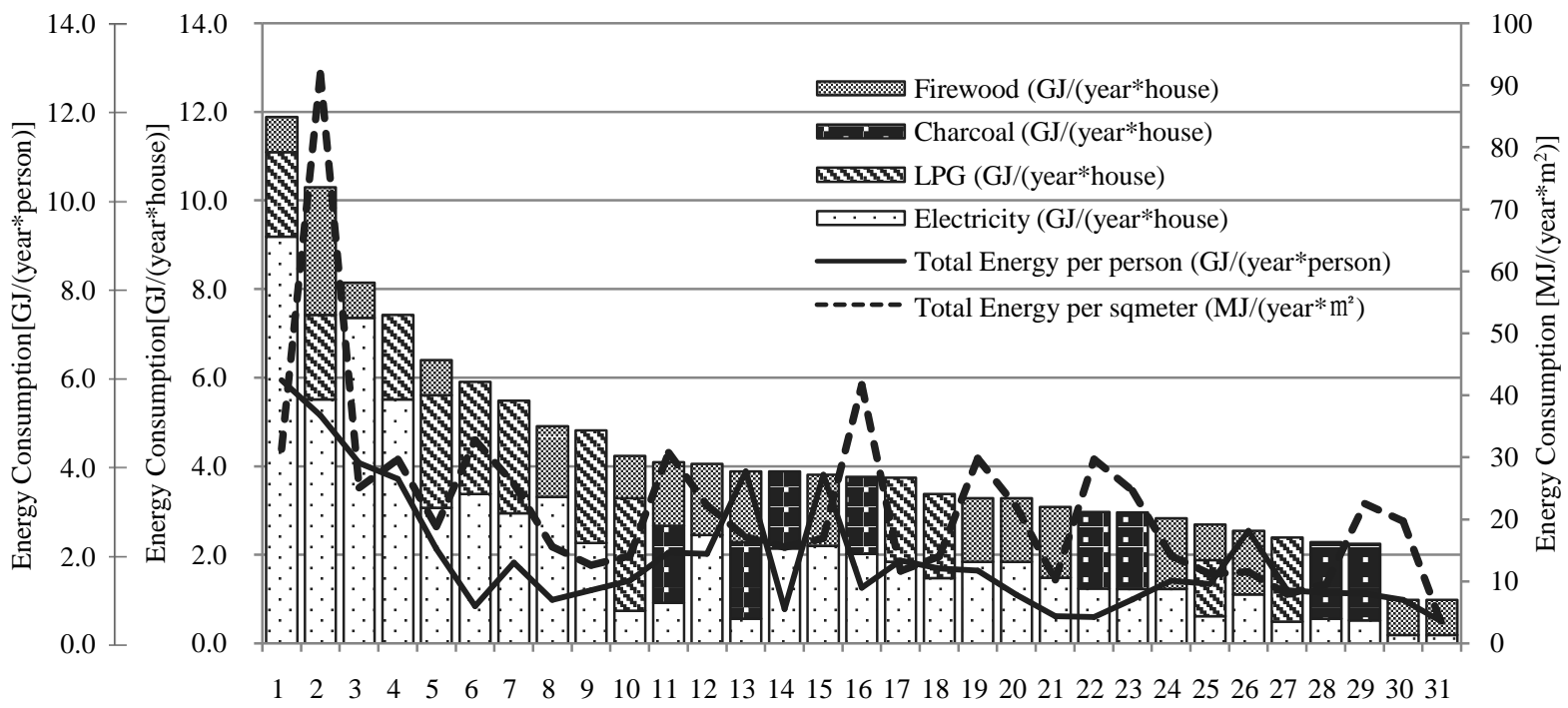

Figure 6. Annual energy consumption by household.

\subsection{Residential Lifestyle}

In the questionnaire, the research team included all aspect of daily behavior which may have influence on household energy use. Sleep length, sleeping hours, meal time, the start time and the end time of work and also family time such as watching TV or other entertainment activities were investigated. Then by average (the average method were used due to there is no significance different between each house), the village lifestyle can be summarized in Figure 7 and Figure 8. Most of the householders return home at 17:00, then go to sleep at 22:00. Living room which designated directly in the front of the main door (Figure 10) was being the central of family activities. 


\section{Statistical Analysis on Annual Energy Use and Households Behavior}

\subsection{Classification of Households}

Based on the results of this paper, the various housing type were grouped by its similarity on physical condition which explained in Figure 9. Type 1 is multiple floor housing with single living and dining room. Type 2 is multiple floor housing with double living and single dining room. Type 3 is multiple floor housing with corridor connecting each room, mostly lived by multiple families. Type 4 is single floor housing with living and dining in the same room. All the spaces configurations of each house type were explained in Figure 10.

Floor number is being the main concern to define the group due to the significant difference on housing construction year and its impact to the annual energy consumption. After grouping the house, the influential factors on energy consumption were listed and graded into 18 factors and 5 grades as shown in Table 5.

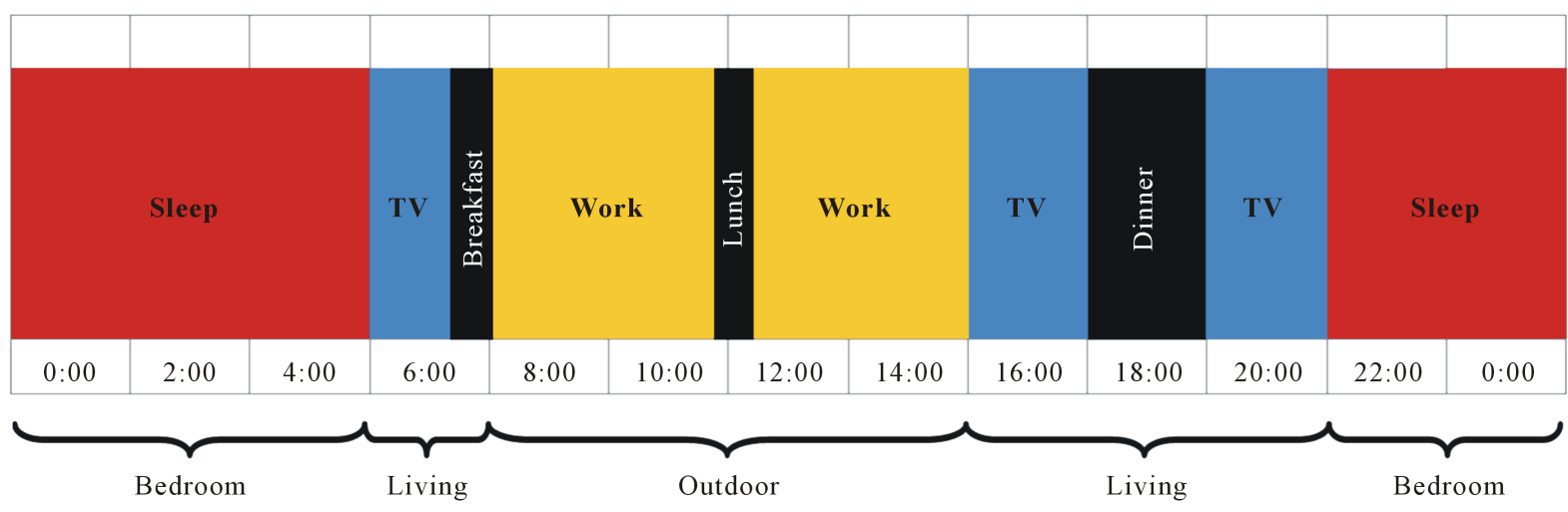

Figure 7. Lifestyle pattern in average.

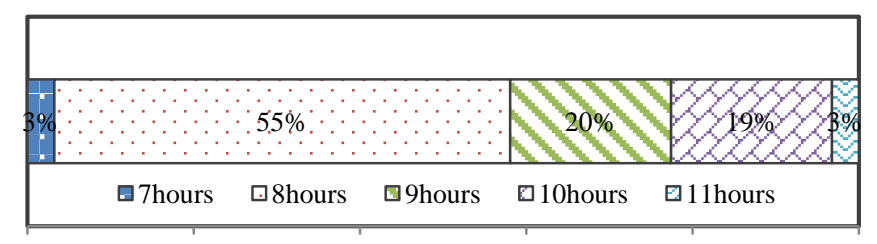

\begin{tabular}{llllll}
\hline 0 & $20 \%$ & $40 \%$ & $60 \%$ & $80 \%$ & $100 \%$
\end{tabular}

Figure 8. Average sleeping hours.

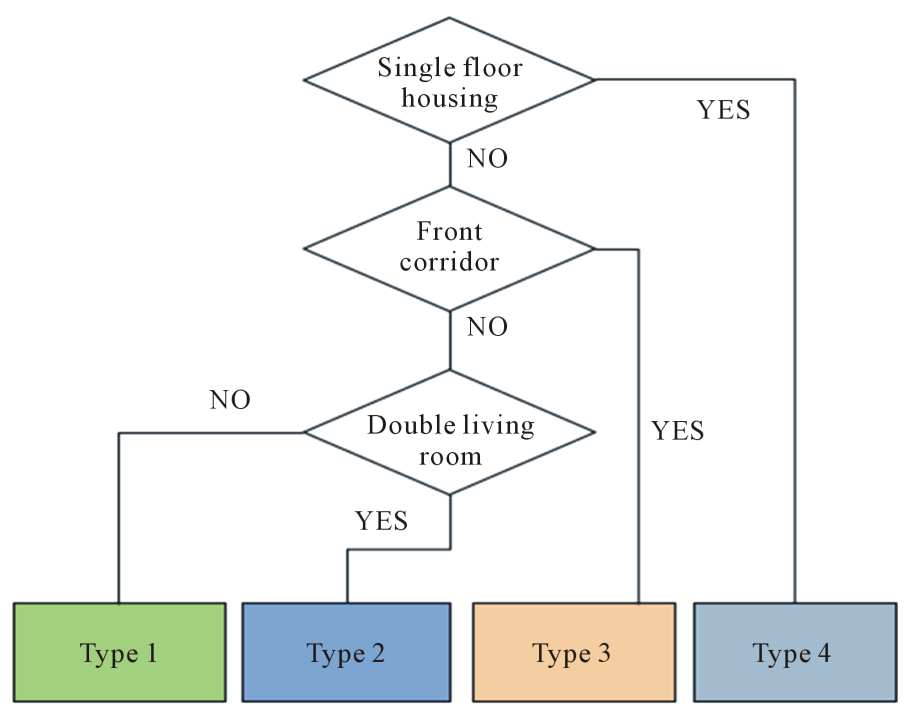

Figure 9. House type grouping method. 


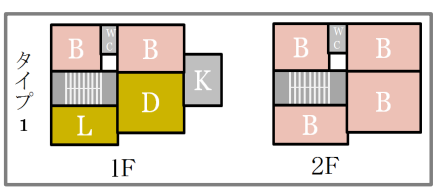

(a)

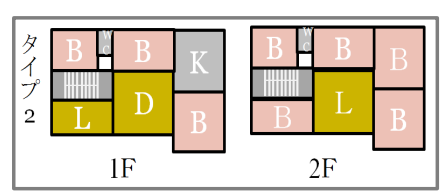

(b)

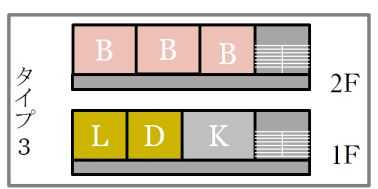

(c)

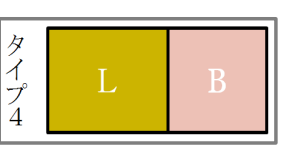

(d)

Figure 10. Space configuration based on house type. (a) Type 1; (b) Type 2; (c) Type 3; (d) Type 4.

Table 5. Grade classification of influential factors.

\begin{tabular}{|c|c|c|c|c|c|c|}
\hline \multirow{2}{*}{ Label } & \multirow{2}{*}{ Factors } & \multicolumn{5}{|c|}{ Grade } \\
\hline & & 1 & 2 & 3 & 4 & 5 \\
\hline $\mathrm{X} 1$ & Family size & $<2$ & $3-4$ & 5 & $6-7$ & $8>$ \\
\hline $\mathrm{X} 2$ & Occupancy & $<2$ & $3-4$ & 5 & $6-7$ & $8>$ \\
\hline X3 & Floor size $\left[\mathrm{m}^{2}\right]$ & $0-100$ & $101-200$ & $201-250$ & $251-300$ & $300>$ \\
\hline $\mathrm{X} 4$ & Land area $\left[\mathrm{m}^{2}\right]$ & $0-100$ & $101-200$ & $201-250$ & $251-300$ & $300>$ \\
\hline X5 & Floor number & 1 & 2 & 3 & - & - \\
\hline $\mathrm{X} 6$ & Room height [m] & $<3$ & 3.2 & 3.3 & 3.5 & $3.5>$ \\
\hline $\mathrm{X} 7$ & Structure & Concrete & Reinforced concrete & Wood & Brick & - \\
\hline $\mathrm{X} 8$ & House age & $<1985$ & $1986-1990$ & 1991-1999 & $2000-2005$ & $2006>$ \\
\hline X9 & Orientation & S & SW & NW & $\mathrm{NE}$ & $\mathrm{N}$ \\
\hline $\mathrm{X} 10$ & Income [*10,000 Yuan] & $<1$ & $1.1-3.5$ & $3.6-4.5$ & $4.6-10$ & $10>$ \\
\hline $\mathrm{X} 11$ & Heating system & Elc. & Firewood & Charcoal & Elc.+Charc. & Elc.+Firew. \\
\hline $\mathrm{X} 12$ & Cooling system & Fan & AC & - & - & - \\
\hline $\mathrm{X} 13$ & AC own. [unit] & 0 & 1 & 2 & 3 & $4>$ \\
\hline $\mathrm{X} 14$ & Hot water & Firew. & Elc+Cha.So.Panel & Cha.+So.Panel & Solar Panel & Elc. \\
\hline $\mathrm{X} 15$ & TV own. & 0 & Always use & - & - & - \\
\hline $\mathrm{X} 16$ & Washing mac. own. & 0 & Always use & - & - & - \\
\hline $\mathrm{X} 17$ & Energy sav. effort & yes & No & - & - & - \\
\hline $\mathrm{X} 18$ & Sleep hours & $<7$ & 8 & 9 & 10 & $11>$ \\
\hline
\end{tabular}

Figure 11 shows the four different house groups and its characteristic by selected factors in Table 3 . Type 1 and Type 4 dominated by family member not more than four person and floor area not more than $250 \mathrm{~m}^{2}$. House in Type 4 has the longest sleeping time and the lowest annual income. Other characteristics such as heatingcooling equipment and housing appliances are also can be grasped by referring Figure 4 and Table 3 .

In terms of the housing energy consumption, Figure 12 shows the comparison on annual electricity, LP gas, charcoal, and firewood. Type 3 has the highest total on energy consumption while Type 4 is the lowest.

\subsection{Influential Factor Analysis}

In order to find the influential factors on housing energy consumption, the multiple regression analysis were conducted using SPSS ver. 20. The housings annual energy consumption was stand as the dependent variable and the 18 factors was the independent variable. In this paper, if the factors have the Partial Correlation Coefficient (PCC) between $\pm 0.0-0.2$ it means the factors are uncorrelated, if PCC $\pm 0.2-0.4$ means the factors have weak correlation, if PCC $\pm 0.4-0.6$ is strong correlation, if PCC $\pm 0.6-0.8$ means the factors have strong correlation, and if $\pm 0.8-1.0$ means the factors have very strong correlation. 

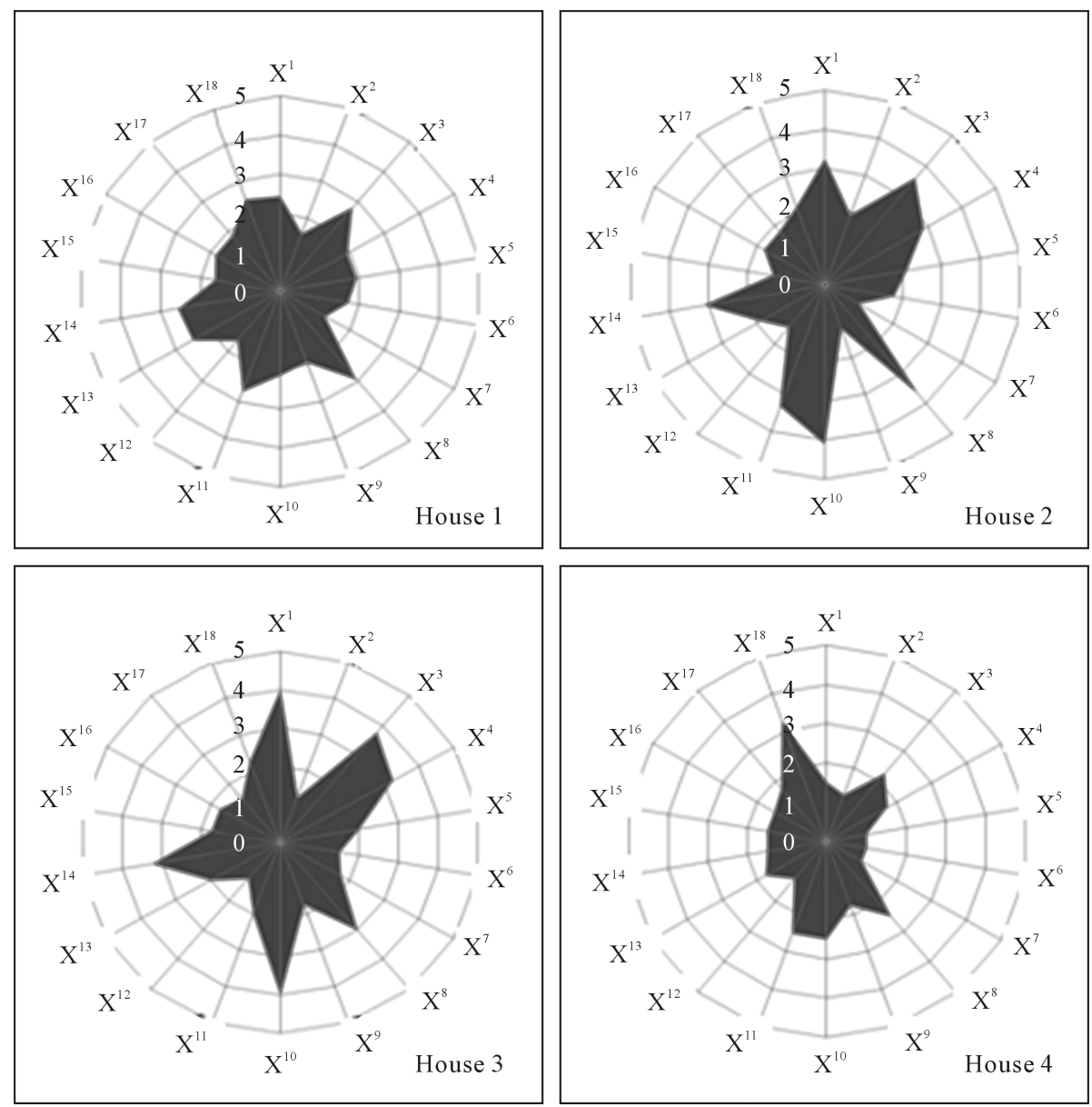

Figure 11. Characteristics comparison of households group.

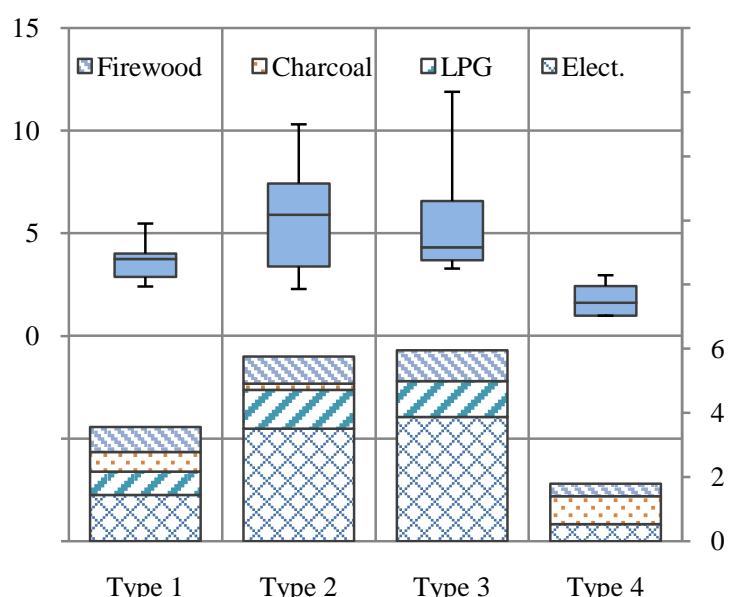

Figure 12. Energy consumption by house type.

The results of correlation analysis are shown in Figure 13. Family member, yearly income, land size, floor number, sleep length, floor number and washing machine ownership has strong influence on increasing the energy consumption. The regression analysis conducted once again using the seven highest factors in Figure 13. Then, in Figure 14, the correlation result between surveyed results and prediction result of yearly energy consumption were shown. The $\mathrm{R}^{2}$ shows 0.754 , it may also be noted that the model fitness $\left(\mathrm{R}^{2}\right)$ is quite high, which 


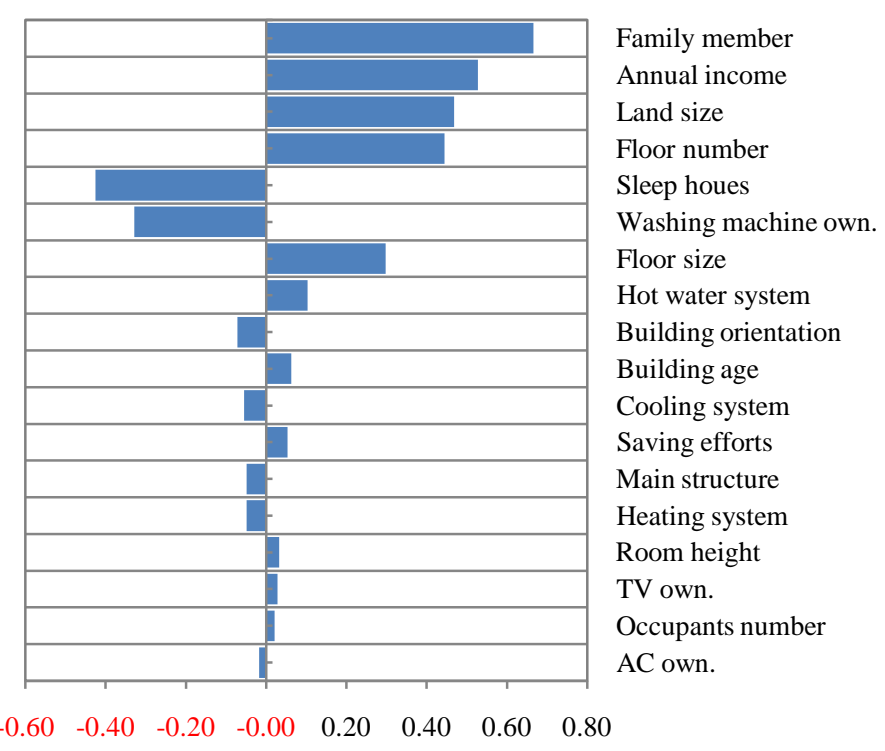

Figure 13. PCC contribution of each factor.

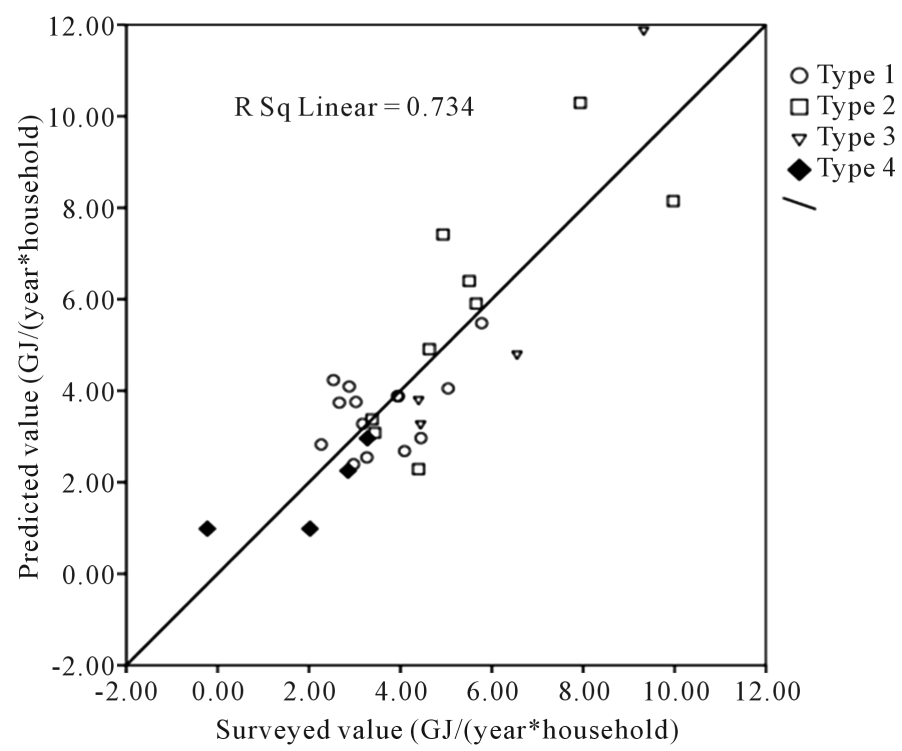

Figure 14. Correlation of surveyed value and predicted value.

is indicating that the seven factors included in the regression can offer a promising and valuable theoretical framework for modeling residential energy consumption. From this result, the prediction equation can be presented as follow:

$$
y=739 x_{1}+359 x_{10}+985 x_{4}+880 x_{5}+1266 x_{18}-513 x_{16}-513 x_{3}-820
$$

where,

$y$ : dependent variable (annual energy use),

$x(n)$ : quantitative independent variables ( $n$ : refer to variables label in Table 5).

\section{Field Measurement on Summer Energy Use}

\subsection{Measurement Outline}

In order to understand the current situation and quality of the indoor thermal environment in the hot season, the 
measurement on energy use and temperature were conducted. In this field measurement, only the electricity use were being the focus of measurement since the consumption of gas, charcoal, and firewood were uncertain so it is difficult to measures. Based on four types of houses which discussed in section 4 of this paper, four houses that represent each type were selected. The data logger were installed on the electricity meter in the middle of spring season and uninstalled in the end of summer season.

\subsection{Houses Target}

Figure 15 shows the measured houses, labeled as House 1, House 2, House 3, and House 4. The ground plan and physical appearance of each house were also shown. Table 6 shows the physical characteristics and household attributes of each type.

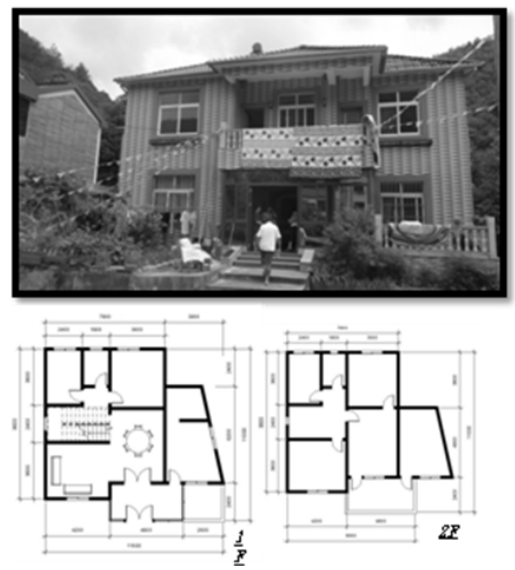

House 1
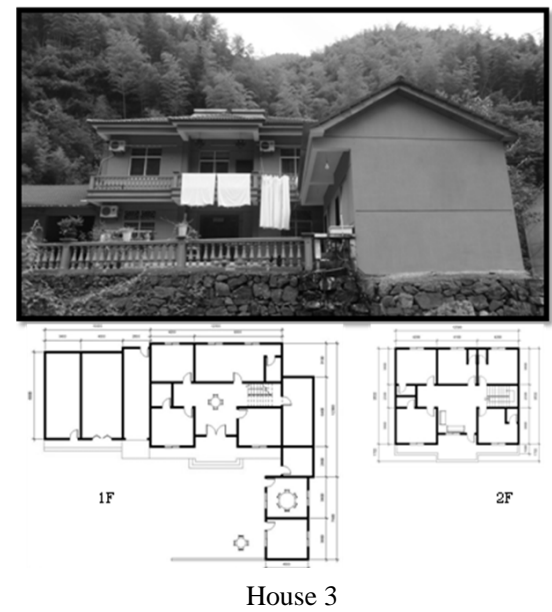
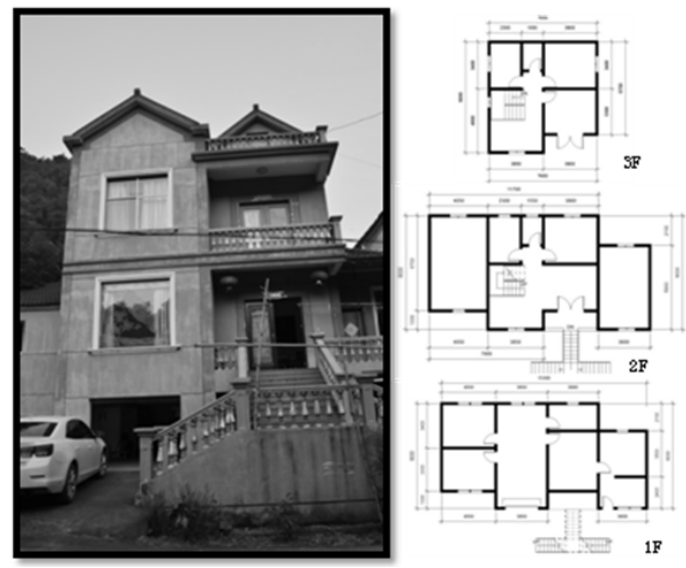

House 2
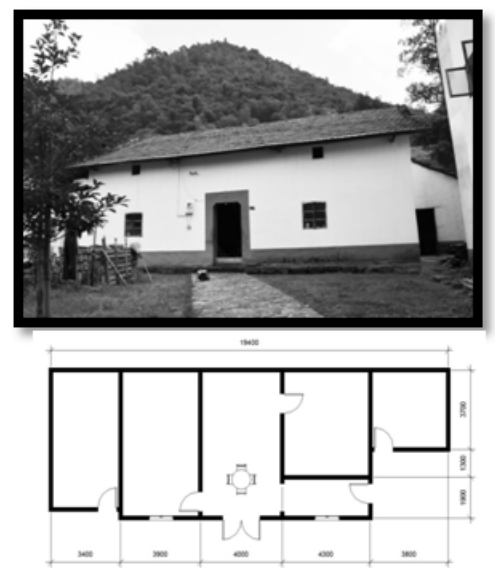

House 4

Figure 15. The appearance and ground plan of measured houses.

Table 6. Physical characteristics by house type.

\begin{tabular}{ccccccccc}
\hline House & Type & $\begin{array}{c}\text { Construction } \\
\text { year }\end{array}$ & $\begin{array}{c}\text { Floor area } \\
\left(\mathrm{m}^{2}\right)\end{array}$ & Direction & $\begin{array}{c}\text { Wall } \\
\text { material }\end{array}$ & $\begin{array}{c}\text { Floor } \\
\text { material }\end{array}$ & $\begin{array}{c}\text { Occupant } \\
\text { number }\end{array}$ & $\begin{array}{c}\text { Air-conditioner } \\
\text { number }\end{array}$ \\
\hline House 1 & 1 & 1996 & 150 & $\mathrm{~S}$ & Brick & Ceramic & 2 & 1 \\
House 2 & 2 & 2001 & 300 & $\mathrm{~S}$ & Brick & Ceramic & 5 & 4 \\
House 3 & 3 & 2006 & 350 & $\mathrm{~S}$ & Brick & Ceramic & 2 & 8 \\
House 4 & 4 & 1980 & 100 & SE & Soil & Concrete & 2 & 0 \\
\hline
\end{tabular}


House 1 is the most common type of housing in the village. It is two story, constructed in the year of 1996, with floor area about $150 \mathrm{~m}^{2}$, directed to the south, using brick as material of the wall, using ceramic tile as floor material, occupied by two people, and using one unit of electric air-conditioner. House 2 is three story of building, has two living rooms in second and third floor, occupied by five people, and owned four units of electric air-conditioner. The floor area of House 2 is two times bigger than House 1 and it is newer (constructed in 2001). House 3 is the biggest type compare to other types even the floor number is only two. House 3 installed electric air-conditioner almost in all of the rooms. This type of house sometimes used also to receive the guest like in hotels, since the village is increasingly popular for village tourism. House 4 is the oldest type, only $100 \mathrm{~m}^{2}$ of floor area, and built from soil. House 4 is not using electric-air conditioner like the other type of houses. This type of housing is mostly occupied by elder couples.

\subsection{Measurement Results}

The thermometer recorders were put in all of the rooms in the houses, but in this paper the results of average temperature in rooms which always used only are showed, such as in living room and the main bedroom. Figure 16 shows the maximum, minimum, and mean of one day temperature in the peak day of summer, which is July 23. Average temperature in living room and bedroom of House 1 is extremely different. It is because in the House 1 the air-conditioner were installed only in the bedroom. In the daytime, the families are going to work outside of the house, so they don't think need to install another air-conditioner in the living room. The result of House 2 shows that the ranges of room's temperatures are not significantly changing during one day. Most of family's member in House 2 prefers to do activities in living room rather in the bedroom in the day time. House 3 has more range of average temperature than House 2, normally they only use electricity when it is hot, and turn it off when they feel it is not too hot. In the other hand, the bedroom and living room in House 4 is in the same room, and it is shows that even the House 4 did not use electric air-conditioner the temperature averages are still lower than House 2 and House 3.

Figure 17 shows the comparison results of House 1, House 2, House 3, and House 4 in terms of daily energy use and its correlation with average room temperatures. The data presented in Figure 17 were selected only in the day with the highest temperature in month during July to September 2014. When the outside temperature (balcony or terrace of the houses) was high the electricity use was also become higher. It means there is big influence on air-conditioner use during the summer season, except for the House 4. Compare to the other houses, House 4 has the lowest and very stable electricity use every month. House 4 only used the electric fan for their cooling equipment during the hot season. The peak of summer temperature was in July 23 with the highest outdoor temperature reached more than 40 degree Celsius in 14:00.

Figure 18 shows the comparison of monthly average electricity use value among different type of houses. Except the electricity use of House 4, the consumption value of House 1, House 2, and House 3 increased significantly after the end of June. Compared to average electricity use in May, the average electricity use of House 1, House 2, and House 3 in July was increased for 15\%, 121\%, and 105\% respectively. Contrary, the average electricity of House 4 was decreased $0.6 \%$ compared to July.

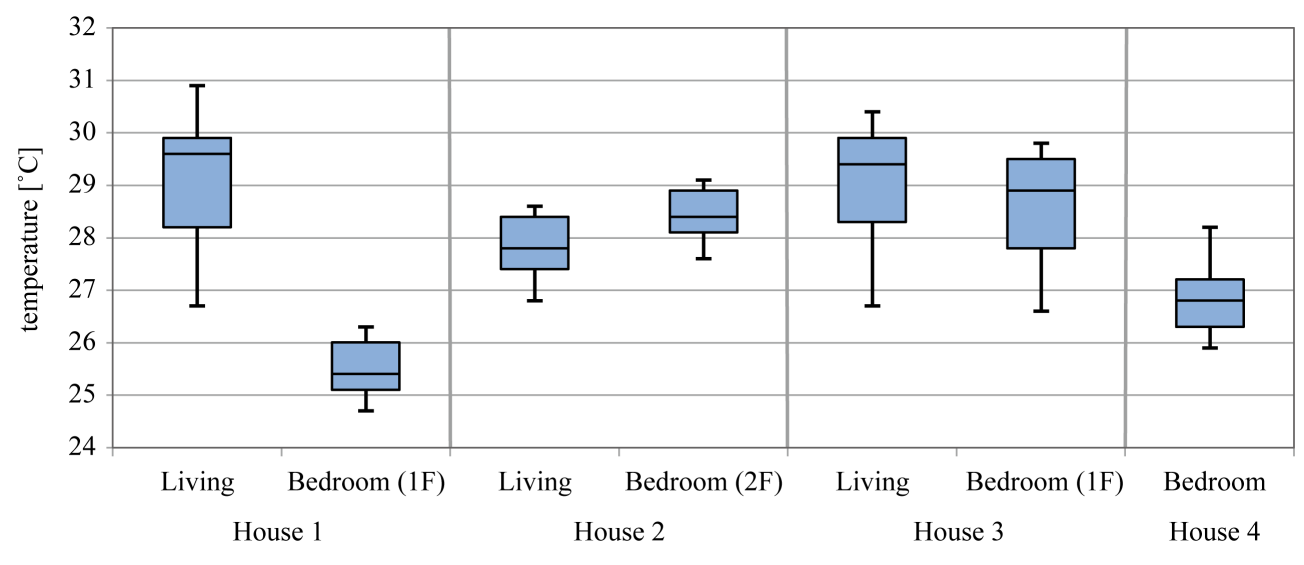

Figure 16. Average temperature of four houses during the summer peak (July 23). 

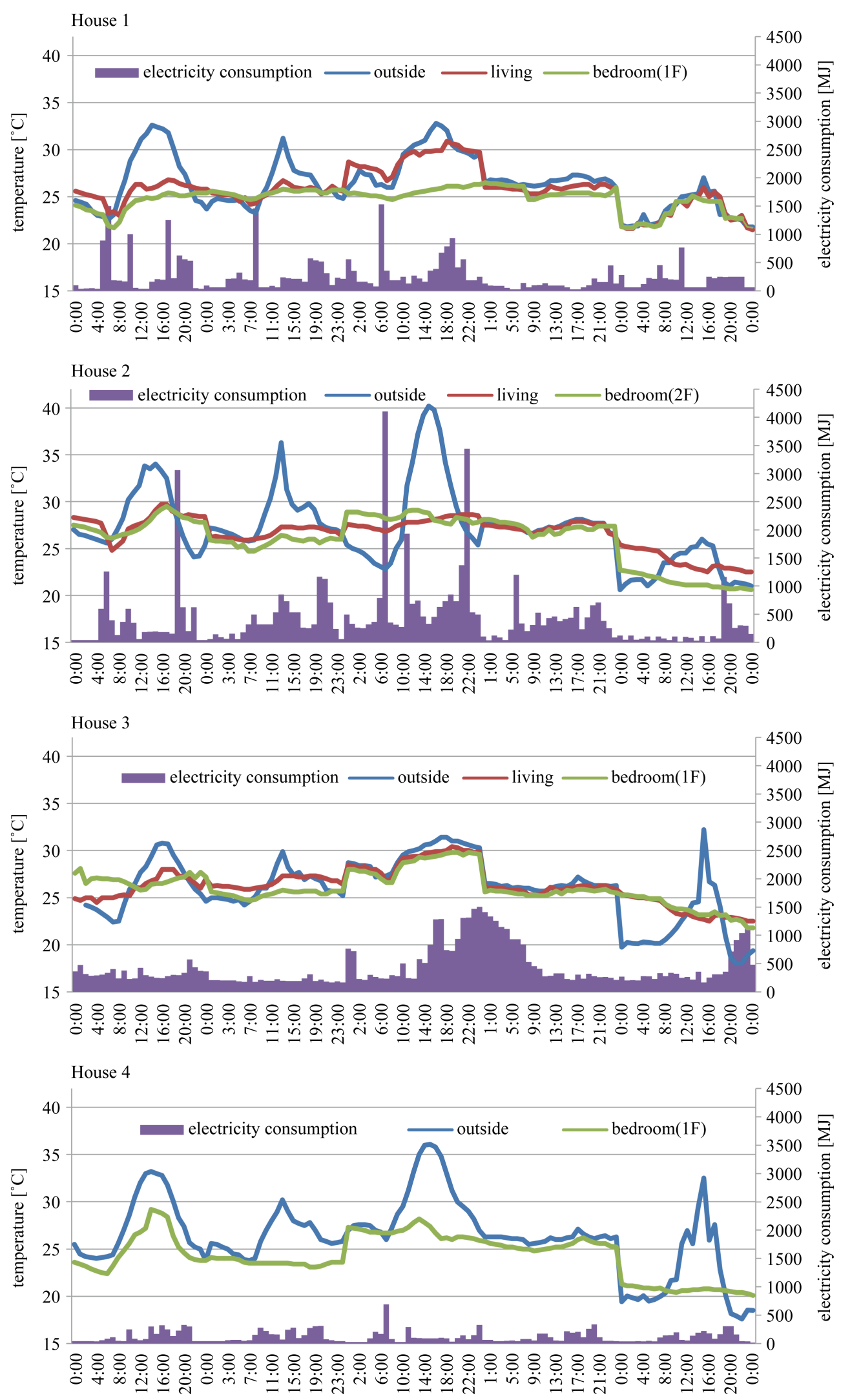

Figure 17. Temperature and electricity consumption of each house during the investigation. 


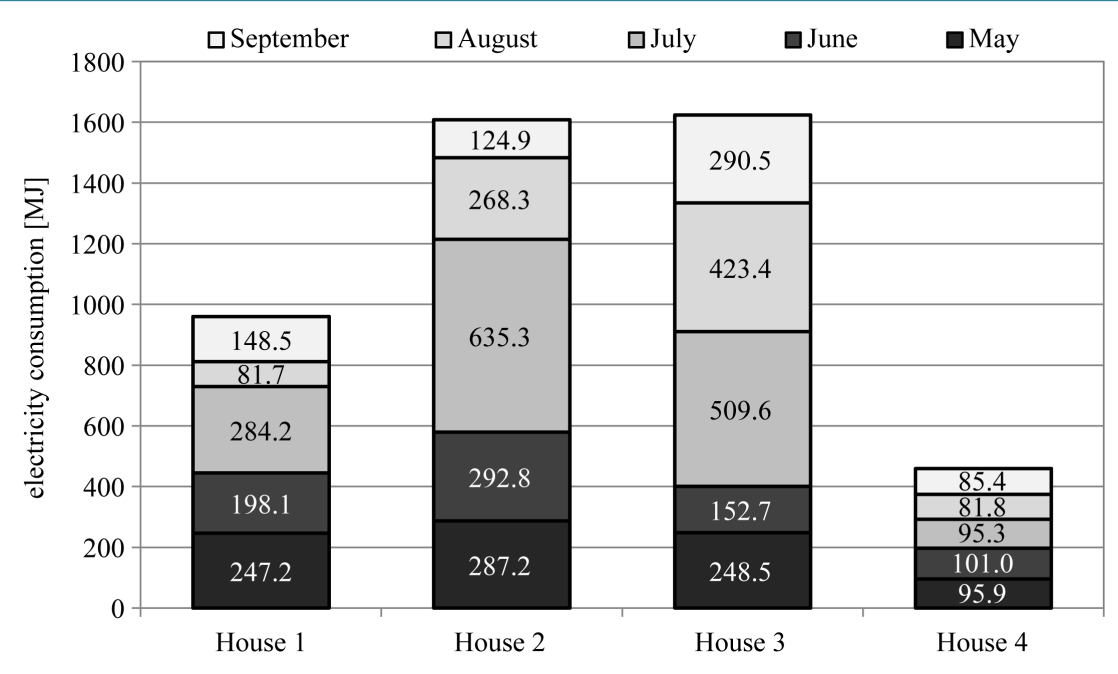

Figure 18. Monthly average of electricity consumption by the house type.

\section{Conclusions}

The conclusions of these studies are described as below:

1) The two person family member in households accounted for about $50 \%$ from total feedback, and it was become common in the village. Means the spaces they built were not follows the need but more than investment in housing, if these phenomenons continue the environment damage will increase faster.

2) The houses which age for 5 years or less, shows very big number on total floor area, but in the other hand only few people lived there.

3) Households that do not own the AC were about $50 \%$ even the area is still comfortable to be lived in summer, but due to the increase of lifestyle it is going to increase the ownership of AC.

4) The energy consumption vary highly, there are nearly ten times difference between the highest and the lowest. It is shows that the economic condition of some householders is under the living standard but in the same area also there are householders lived above the living standard.

5) The annual energy use of people in the village are highly influenced by family number, yearly income, land size, floor number, sleep length, floor number and washing machine ownership. AC use influence is low maybe because the ownership of AC is very low, only half from the total respondents are using AC.

Further, the study on indoor thermal comfort and energy consumption by appliances usage were needed in the future, since there are significant effects on household appliances factor in the changes of energy use pattern. In the other hand the investigation on cold season are also needed to understand the housing performance in the cold weather.

\section{Acknowledgements}

This research was the cooperation between The University of Kitakyushu Japan with Zhejiang University of China and sponsored by Natural Science Foundation of China (No. 51238011). Thanks to Mr. Ian Jarvis (The University of Kitakyushu) for checking the English.

\section{References}

[1] Wang, X.H. and Feng, Z.M. (2001) Rural Household Energy Consumption with the Economic Development in China Stages and Characteristic Indices. Energy, 29, 139-147.

[2] Wang, X.H., Dai, X.Q. and Zhou, Y.D. (2002) Domestic Energy Consumption in Rural China: A Study on Sheyang County of Jiangsu Province. Biomass and Bioenergy, 22, 251-256. http://dx.doi.org/10.1016/S0961-9534(02)00013-2

[3] Gu, S.H. and Lie, W.Q. (1997) Research on the Rural Household Energy Consumption under the System of Market Economy. Rural Energy, 3, 3-6.

[4] Feng, Z.M. and Wang, X.H. (1996) Analysis on the Rural Household Living Energy Consumption in China. Rural Energy, 3, 3-5. 
[5] Wang, X.H. and Feng, Z.M. (2003) Common Factors and Major Characteristics of Household Energy Consumption in Comparatively Well-Off Rural China. Renewable and Sustainable Energy Reviews, 7, 545-552. http://dx.doi.org/10.1016/S1364-0321(03)00080-7

[6] Zang, M. and Fang, Y.G. (2013) Analysis of Rural Residential Commercial Energy Consumption in China. Energy, 52, 222-229. http://dx.doi.org/10.1016/j.energy.2013.01.039

[7] He, B.J., Li, Y. and Miao, Y. (2014) Building Energy Efficiency in China Rural Areas: Situation, Drawbacks, Challenges, Corresponding Measures and Policies. Sustainable Cities and Society, 11, 7-15. http://dx.doi.org/10.1016/j.scs.2013.11.005

[8] Nagasaki, K., Hayashi, T. and Nomura, K. (2010) Housing Energy Use towards Low Carbon Community in Asia. Part 1. Field Survey of Urban Apartment in China. Architectural Institute of Japan. Kyushu Branch No 49, 2010-03. 